\title{
Promosi Penjualan Produk Luberground di Instagram @LUBERGROUND.ID
}

\author{
Intan Trias Anisha, Anne Ratnasari \\ Islam Bandung, Indonesia. \\ *intantriasa08@gmail.com, anneratnasari10@gmail.com
}

Prodi Manajemen Komunikasi, Fakultas Ilmu Komunikasi, Universitas

\begin{abstract}
Luberground is one of the fast food culinary restaurants by applying the concept of an open kitchen because the kitchen for making food is in the front and open. With the PSBB in the Covid-19 Pandemic situation, this restaurant took advantage of its sales promotions through Instagram due to the limited direct or offline sales promotions during the Covid-19 pandemic. The purpose of this study was to determine the form of sales promotion on Instagram, content, obstacles and efforts to overcome them, as well as the reasons for photos and videos on Instagram feeds to become a mainstay. So this research is expected to provide more knowledge for other researchers about Sales Promotion on Instagram, and it is hoped that there will be more developments for Luberground regarding forms and content as sales promotion activities. This study uses a qualitative research method with a case study approach. The data collection techniques used were observation, interviews, documentation, and literature study. The research subjects were Operations Manager, Social Media Marketing, Luberground Employees and Consumers. The results of the research found by researchers are that in promoting their product sales, Luberground provides forms of sales promotion through Instagram such as discounts, free products and special package promos. Then in carrying out its sales promotion activities, Luberground creates interesting content to introduce and market the available products. The content is in the form of photo content regarding product photos, activity photos, and daily promo photos. Then there is also video content about videos of the product manufacturing process and videos about available promos that are packaged in a short 1 minute video story. Uniquely, Luberground creates social experience video content to introduce its newest product and at the same time invite consumers to do good. The perceived obstacles when conducting sales promotions on Instagram are the limited direct sales promotion activities and the Instagram algorithm error in uploading sales promotion content. Efforts to overcome these obstacles are by optimizing online promotional activities assisted by the personal Instagram of Luberground staff and other employees to reach a wider target audience.
\end{abstract}

Keywords: Sales Promotion, Fast Food Culinary, Instagram, Luberground

Abstrak. Luberground adalah salah satu restaurant kuliner cepat saji dengan menerapkan konsep open kitchen karena dapur pembuatan makanannya yang berada di depan dan terbuka. Dengan adanya PSBB di situasi Pandemi Covid-19 restaurant ini memanfaatkan promosi penjualannya melalui Instagram karena terbatasnya promosi penjualan langsung atau offline selama pandemi Covid-19. Tujuan penelitian ini untuk mengetahui bentuk promosi penjualan di Instagram, konten, hambatan dan upaya untuk mengatasinya, serta alasan foto dan video pada feeds Instagram menjadi andalan. Maka penelitian ini diharapkan dapat memberikan pengetahuan yang lebih bagi peneliti lain mengenai Promosi Penjualan di Instagram, serta diharapkan adanya perkembangan lebih bagi Luberground mengenai bentuk dan konten sebagai kegiatan promosi penjualannya. Penelitian ini menggunakan metode penelitian kualitatif dengan pendekatan studi kasus. Teknik pengumpulan data yang digunakan adalah, observasi, wawancara, dokumentasi, dan studi kepustakaan. Subjek penelitan yaitu Manager Operasional, Marketing Media Sosial, Karyawan dan Konsumen Luberground. Hasil penelitian yang ditemukan oleh peneliti yaitu dalam melakukan promosi penjualan produknya Luberground memberikan bentuk promosi penjualannya melalui Instagram seperti potongan harga, gratis produk dan promo paket spesial. Kemudian dalam melakukan kegiatan promosi penjualannya Luberground membuat konten-konten yang menarik guna memperkenalkan dan memasarkan produk yang tersedia. Konten tersebut berupa konten foto mengenai foto produk, foto kegiatan, dan foto promo harian. Lalu ada pula konten video mengenai video proses pembuatan produk dan video mengenai promo yang tersedia yang dikemas dalam sebuah video cerita pendek berdurasi 1 menit. Uniknya Luberground membuat konten video social experience guna memperkenalkan produk terbarunya dan sekaligus mengajak konsumen melakukan kebaikan. Hambatan yang dirasakan saat melakukan promosi penjualan di Instagram adalah terbatasnya kegiatan promosi penjualan secara langsung dan algoritma Instagram error dalam mengunggah konten-konten promosi penjualan. Upaya mengatasi hambatan tersebut yaitu dengan mengoptimalkan kegiatan promosi secara online dibantu dengan Instagram milik pribadi staff dan karyawan Luberground lainnya agar mencapai target khalayak yang lebih luas.

Kata Kunci: Promosi Penjualan, Kuliner Cepat Saji, Instagram, Luberground. 


\section{A. Pendahuluan}

Promosi penjualan merupakan salah satu bentuk kegiatan dalam komunikasi pemasaran selain iklan, personal selling, dan publisitas. Kegiatan ini sering kali dilakukan bersama-sama dengan kegiatan promosi lainnya, dan tidak memerlukan biaya yang terlalu banyak karena saat ini promosi penjualan yang dimaksimalkan adalah promosi penjualan melalui media sosial. Menurut Kotler dan Keller (2016), "Media sosial digunakan sebagai alat komunikasi pemasaran unntuk meningkatkan kesadaran konsumen terhadap produk, meningkatkan image produk, dan berakhir pada peningkatan penjualan".

Media sosial menjadi wadah yang efektif untuk melakukan kegiatan promosi penjualan. Terlebih media sosial yang digunakan adalah media sosial yang penggunanya banyak dan dapat dijangkau dimana saja dan kapan saja. Maka dari itu Instagram dipilih sebagai media sosial yang dimanfaatkan oleh perusahaan ini. Dilihat pada fitur-fitur yang ada pada Instagram, sangat banyak kegunaannya untuk melakukan promosi penjualan produknya. Terutama Instagram adalah platform yang cocok untuk mencapai target pasar Luberground. Berbagai macam bentuk kegiatan promosi penjualan yang telah dilakukan Luberground di Instagram. Salah satu yang rutin dilakukan adalah dengan memberikan potongan harga yang dikemas dengan konten video dalam bentuk sebuah cerita yang membuat publik penasaran.

Luberground membuktikan dengan promosi penjualan yang maksimal secara online bisa membuat Luberground bertahan sampai sejauh ini. Saat tidak sedikit perusahaan kuliner yang harus tutup karena keadaan pandemi, Luberground memanfaatkan platform media sosial yang ada untuk dapat memasarkan produknya dengan menggunggah konten semenarik mungkin sebagai kegiatan dari promosi penjualan produk restaurant ini. Konten yang berhasil menarik perhatian peneliti terdapat pada konten unggahan video dimana dalam video tersebut memperkenalkan sebuah produk Luberground dan disertai kegiatan social experience untuk mengajak para konsumen dan khalayak lainnya berbagi kebaikan.

Luberground memaksimalkan konten tersebut sebagai ciri khas dalam mempromosikan produknya dengan menjadikan sosial Instagram sebagai alat promosinya. Seperti yang dikatakan Priska sebagai Manager Operasional saat wawancara tanggal 2 Februari 2021, "Promosi penjualan online melalui Instagram akan mudah dijangkau siapa saja dan dimana saja, jadi itu yang membuat masyarakat mengenal Luberground dan peluang pembeli juga akan semakin banyak meskipun masih dalam keadaan PSBB ini”.

Ada pula hambatan yang terjadi karena promosi penjualan dimaksimalkan secara online yang akhirnya menuntut untuk selalu mengunggah konten terbaru yang lebih kreatif untuk menarik perhatian calon pembeli. Terkadang, Marketing Media Sosial Luberground merasa kesulitan untuk membuat konten foto dan video baru yang lebih menarik itu untuk dibagikan di Instagram.

Berdasarkan pada penelitian ini, keunikan yang membuat peneliti tertarik untuk diteliti adalah unggahan konten video pada Instagram @luberground.id dalam mengemas bentuk dan kegiatan promosi penjulan produknya. Konten yang berhasil menarik perhatian peneliti berupa konten video mengenai produk terbaru dari Luberground yang dikemas dengan mengandung ajakan untuk berbagi kebaikan yang biasa disebut social experience.

\section{B. Metodologi Penelitian}

Metode penelitian ini mengamati suatu fenomena atau kondisi yang alamiah. "Penelitian kualitatif berlandaskan pada filsafat postpositivisme, karena digunakan untuk meneliti pada kondisi objek yang alamiah, (sebagai lawannya eksperimen) dimana peneliti adalah sebagai instrument kunci, pengambilan sampel sumber data dilakukan dengan cara purposive dan snowbaal, teknik pengumpulan trianggulasi, analisis data induktif' (Sugiyono,2011)

Teknik Pengumpulan Data melalui Observasi, Wawancara Mendalam, Dokumentasi dan Studi kepustakaan. Lalu teknik analisis data peneliti menggunakan Pengumpulan Data, Reduksi Data, Penyajian Data dan Verivikasi.

Uji Keabsahan Data yang dilakukan peneliti adalah Teknik Triangulasi. 


\section{Hasil Penelitian dan Pembahasan}

Bentuk Kegiatan Promosi Penjualan Produk Luberground di Instagram

Pada promosi penjualan terdapat pula beragam bentuk promosi seperti menurut pendapat Kotler dan Armstrong (2008:117), Bentuk promosi penjualan bermacam-macam contohnya potongan harga, kupon, atau giveaway. Definisi pada bentuk promosi tersebut berkaitan dengan bentuk promosi yang ditemukan pada penelitian ini.Terdapat 3 bentuk kegiatan promosi penjualan produk Luberground seperti berikut :

1. Potongan Harga

2. Promo Gratis Produk

3. Promo Paket Spesial All You Can Eat

\section{Konten Promosi Penjualan Dalam Memasarkan Produk Luberground di Instagram}

Konten merupakan pokok, tipe, atau unit dari informasi digital. Konten dapat berupa teks, citra, grafis, video, suara dan lain-lain. Dengan kata lain konten adalah semua hal yang dapat dikelola dalam format elektronik (Simarmata, 2011). Terkait penjelasan mengenai konten Luberground merancang, membuat dan mengunggah sebuah konten dalam melakukan promosi penjualan guna mengenalkan dan memasarkan produknya di Instagram. Setiap konten yang dibuat, tidak hanya memperkenalkan produk saja akan tetapi Luberground mengemasnya dengan sebuah cerita pendek yang mengandung makna. Konten yang disajikan oleh Luberground adalah konten berbentuk foto dan video yang dikemas unik dan menarik. Selain unik dan menarik, konten harus dipastikan memiliki nilai komunikasi yang mengandung pesan informatif maupun pesan persuasif. Seperti berikut ini:

1. Konten Foto Mengenai Produk

2. Konten Foto Video Proses Pembuatan Produk

3. Konten Video Mengenai Promo Luberground

4. Konten Video Social Experience

\section{Hambatan Promosi Penjualan Produk Luberground dan Upaya Mengatasinya}

Hambatan promosi penjualan produk Luberground di Instagram @luberground.id. Hambatan terbagi menjadi dua, yaitu hambatan dalam melakukan bentuk kegiatan promosi dan hambatan dalam membuat konten promosi. Hambatan dalam bentuk kegiatan promosi penjualan yang timbul adalah algoritma Instagram yang tidak jelas atau error. Algoritma tersebut membuat bentuk promosi yang sudah diunggah terhambat dan tidak sampai pada khalayak terutama followers @ luberground.id. Menurut Fajar (2009) Hambatan Media adalah hambatan yang terjadi dalam penggunaan media komunikasi. Hambatan kedua terdapat pada pembuatan konten yang disajikan di Instagram, yaitu Kurangnya sumber daya manusia pada divisi Marketing Media Sosial membuat kewalahan dalam proses pembuatan konten yang harus disajikan. Menurut Malayu S.P Hasibuan (Hasibuan, 2012: 255) hambatan sumber daya manusia adalah manusia sebagai makhluk hidup tidak dapat dikuasi sepenuhnya seperti mesin. Hal tersebut berkaitan dengan Fahrurrazi sebagai Marketing Media Sosial sekaligus admin @luberground.id karena ia hanya seorang diri dalam merencanakan hingga membuat konten yang harus disajikan pada Instagram. Setelah itu Fahrurrazi juga melakukan proses editing konten tersebut seorang diri. Terkadang ia kesulitan dalam mncari inspirasi baru untuk membuat konten yang lebih baru dan lebih kreatif.

Upaya dalam mengatasi hambatan tersebut adalah Fahrurrazi meminta bantuan tim lain yang memiliki waktu senggang dan seseorang yang mengerti bidang konten juga untuk membantunya membuat konten. Dengan cara itu Fahrurrazi menganggap aka nada inspirasi atau pendapat baru dalam perancangan hingga pembuatan konten yang lebih unik dan kreatif. Kemudian upaya lainnya adalah Fahrurrazi menampung banyak inspirasi dahulu dan setelah itu memilih mana yang harus ia kembangkan.

\section{Fitur Dalam Melakukan Promosi Penjualan Produk Luberground di Instagram}

Fitur Instagram feeds dan insta story dimanfaatkan dalam mengunggah foto dan video yang dikemas menjadi sebuah konten yang unik dan menarik guna mempromosikan penjualan 
produk Luberground. Menurut Fahrurrazi Instagram feeds dan Instagram Story merupakan salah satu hal yang diperhatikan oleh pengguna Instagram lain ketika mengunjungi akun Instagram @ luberground.id.

\section{Kesimpulan}

Berdasarkan pembahasan yang telah diuraikan untuk menjawab pertanyaan penelitian yang berjudul "Promosi Penjualan Kuliner Cepat Saji di Instagram (Studi Kasus Promosi Penjualan Produk Luberground di Instagram @luberground.id)" dapat ditarik kesimpulan sebagai berikut:

1. Bentuk kegiatan promosi penjualan produk Luberground di Instagram yaitu dengan mengunggah berbagai macam promosi yang tersedia seperti promo potongan harga, promo gratis produk dan promo paket spesial. Bentuk-bentuk promosi tersebut diunggah dengan memanfaatkan fitur yang tersedia di Instagram.

2. Konten yang disajikan dalam memasarkan produk Luberground di Instagram berupa unggahan konten foto dan video. Konten foto antara lain foto mengenai produk, foto kegiatan di dalam restaurant, foto interaksi keryawan dan pelanggan, dan foto informasi mengenai promo-promo yang tersedia. Konten video antara lain video mengenai proses pembuatan produk, dan yang unik adalah penyajian sebuah promo yang dikemas menjadi sebuah cerita dalam konten video yang berdurasi 1 menit kemudian diunggah ke dalam Instagram feeds @luberground.id. Terdapat pula Konten Social Experience guna memperkenalkan produk baru dan ajakan dalam berbagi kebaikan.

3. Hambatan terdapat pada kegiatan promosi penjualan dan penyajian konten. Hambatan kegiatan promosi timbul karena algoritma Instagram yang error sehingga bentuk promosi terhalangi oleh unggahan-unggahan lain di Instagram. Selain itu situasi pandemi saat ini sangat membatasi kegiatan promosi penjualan secara langsung. Upaya dalam mengatasi algoritma Instagram yang error yaitu dengan bantuan staff dan karyawan untuk mengunggah serta membagikan bentuk promosi penjualan tersebut dalam Instagram pribadinya. Lalu upaya lainnya adalah tetap memaksimalkan promosi penjualan secara online.

4. Fitur yang diandalkan dalam kegiatan promosi penjualan produk Luberground adalah Instagram Feeds dan Instagram Story. Fitur Instagram feeds dan insta story dimanfaatkan dalam mengunggah foto dan video yang dikemas menjadi sebuah konten yang unik dan menarik.

\section{Acknowledge}

Peneliti mengucapkan terima kasih kepada narasumber dan segenap staff karyawan Luberground juga para narasumber lain yang sudah mendukung dan membantu dalam memberikan data maupun informasi untuk tujuan penelitian ini.

\section{Daftar Pustaka}

[1] Alma, Buchari. 2011. Manajemen Pemasaran Dan Pemasaran Jasa. Bandung: Alfabeta.

[2] Anggito, Albi, and Johan Setiawan. 2018. Metode Penelitian Kualitatif. Kab. Sukabumi: CV Jejak.

[3] Ardhi, Yudha. 2013. Merancang Media Promosi Yang Unik Dan Mearik. Yogyakarta: Serambillmu Semesta.

[4] A, Shimp, T. (2003). Periklanan Promosi \& Aspek Tambahan Komunikasi Pemasaran (Jilid 1 Ed). Jakarta: Erlangga.

[5] Atmoko Dwi, B. (2012). Instagram Handbook Tips Fotografi Ponsel. Jakarta: Media Kita

[6] Firmansyah, M. Anang. 2020. Komunikasi Pemasaran. Pasuruan: CV. Penerbit Qiara Media.

[7] Ghazali, Miliza. 2016. Buat Duit Dengan Facebook dan Instagram. Malaysia: Publishing House

[8] Herdiyan Maulana, Gumgum Gumelar. 2013. Psikologi Komunikasi dan Persuasi. Jakarta: Akademia Permata

[9] Kasmir. 2004. Pemasaran Bank. Jakarta : Prenada Media 
[10] Kotler, Phillip, and Gary Amstrong. 2008. Prinsip-prinsip Pemasaran. Jakarta: Erlangga.

[11] Kotler, P. \& K. (2009). Manajemen Pemasaran Edisi 13 Jilid 1. Jakarta: Erlangga

[12] Kotler, P \& Keller, K. . (2012). Manajemen Pemasaran Jilid I Edisi 12. Jakarta: Erlangga.

[13] Kuswarno, Engkus. 2010. Menulis Ilmiah: Metode Penelitian Kualitatif. Jakarta: Yayasan Pustaka Obor Indonesia.

[14] Moleong, L.J. 2014. Metodologi Penelitian Kualitatif. Edisi Revisi. Bandung: Remaja Rosdakarya.

[15] Nasrullah, Rulli. 2016. Media Sosial Perspektif Komunikasi. Bandung: Simbios Rekatama Media.

[16] Rifai, 2012. Kualitatif: Teori, Praktek\&Riset Penelitian Kualitatif Teologi. Sukoharjo: BornWin's Publishing

[17] Sugiyono. 2017. Metode Penelitian Kuantitatif, Kualitatif, dan R\&D. Bandung: Alfabeta

[18] Sugiyono. 2020. Metode Penelitian Kualitatif (Untuk Penelitian Yang Bersifat Eksploratif, Enterpretif, Interaktif Dan Konstruktif). Bandung: Alfabeta.

[19] Suherman, Eman. 2010. Business Enterpreneur. Bandung: Alfabeta

[20] Tjiptono, Fandy. (2002). Strategi Pemasaran. Yogyakarta : Penerbit Andi.

[21] Ratnasari, Anne, Yusuf Hamdan, Aan Julia. 2017. "Promosi Penjualan Produk Melalui Instagram." InterKomunika. https.//scholar.google.co.id

[22] "Emil Bersyukur Bandung Ditetapkan sebagai Destinasi Wisata Kuliner Nasional", https://bandung.bisnis.com Tanggal akses 1 Maret 2021, pukul 12:53 WIB. 